\title{
Fetal Heart Rate and Transcutaneous Monitoring during Experimentally Induced Hypoxia in the Fetal Dog
}

\author{
ALAN G. MONHEIT, MARTIN L. STONE, AND M. MAURICE ABITBOL \\ Department of Obstetrics and Gynecology, University Hospital, State University of New York at Stony Brook,
} Stony Brook; and the Jamaica Hospital, Jamaica, New York

\begin{abstract}
A model of impaired oxygen delivery, using an acute surgical preparation in the fetal $d o g$, is described. Fetal heart rate, transcutaneous $\mathrm{pO}_{2}$ and $\mathrm{pCO}_{2}$, and tissue pH were simultaneously recorded during hypoxic episodes produced by a series of successive occlusions of the maternal abdominal aorta. Corresponding values were also determined in the arterial blood of the fetus. The following pathophysiologic sequence of events was observed: 1) a latency period with no changes; 2) a drop in $\mathrm{pO}_{2}$ which stabilized later at a lower pressure; 3) late fetal heart rate deceleration, the pattern of which was not related to the progressively deteriorating fetal condition; 4) a progressive increase in $\left.\mathrm{pCO}_{2} ; 5\right)$ a progressive decrease in $\mathrm{pH}$. Abnormal tissue values consistently preceded and were more adversely affected than corresponding blood values. This experimental model demonstrates first that late decelerations of the fetal heart rate are an early sign of fetal hypoxia and second that a fall in fetal blood $\mathrm{pH}$, beyond that level normally seen during labor, occurs relatively late in this pathophysiologic sequence. Between these two, there are intermediary stages that could be continuously monitored in order to identify worsening fetal condition. Continuous tissue $\mathrm{pH}$ and transcutaneous $\mathrm{pO}_{2}$ and $\mathrm{pCO}_{2}$ recording may potentially be of significant clinical value. (Pediatr Res 23:548-552, 1988)
\end{abstract}

\section{Abbreviations}

FHR, fetal heart rate

tc, transcutaneous

t, tissue

UBF, uterine blood flow

Our present knowledge of the pathophysiology of fetal distress is limited by insufficient access to the fetus during labor. Presently only FHR monitoring and intermittent fetal scalp blood sampling (for fetal blood $\mathrm{pH}$ determinations) are used. Continuous FHR monitoring is associated with a high false-positive rate approaching $30 \%$ (1). The disadvantage of fetal scalp blood sampling is that it is done intermittently and is associated with fetal and maternal complication (2). Continuous recording of $\mathrm{pH}, \mathrm{pO}_{2}$, and $\mathrm{pCO}_{2}$ as opposed to intermittent fetal blood sampling may present some benefits (3). Recent progress in tc blood gas and tissue $(\mathrm{t}) \mathrm{pH}$ monitoring has made this a clinically applicable tool (4). Unfortunately, experience with implantation

Received September 23, 1987; accepted January 20, 1988

Reprint requests: M. Maurice Abitbol, M.D., Department of Obstetrics and Gynecology, the Jamaica Hospital, 89th Avenue and Van Wyck Expressway, Jamaica, NY 11418. of an electrode on the fetal scalp is associated with numerous technical difficulties (2). Additionally, values obtained are different from those obtained by blood sampling. As a result of these shortcomings, such equipment has received very limited use.

In a previous report (5) the relationship between arterial blood $\mathrm{pH}, \mathrm{pO}_{2}, \mathrm{pCO}_{2}$, and tpH, tcpO, tcpCO $\mathrm{CO}_{2}$ in the fetal dog was examined. It was demonstrated that, under normal physiological conditions, paired values approximated each other; and that, under stressful fetal conditions, they diverged: changes in the skin and subcutaneous values preceded those derived from central blood sampling.

The purpose of our investigation is to study the combined variations of FHR, fetal $\mathrm{pH}, \mathrm{pO}_{2}$, and $\mathrm{pCO}_{2}$ (arterial and tc), and their sequential interrelationships, as progressive fetal distress is produced in the pregnant dog. A previously described technique (6), consisting of intermittent occlusion of the abdominal aorta of the pregnant dog in order to reduce UBF, was used herein.

\section{MATERIALS AND METHODS}

Herein 12 pregnant dogs were prepared for maternal aortic occlusion and fetal monitoring of different parameters (FHR, $\mathrm{tpH}, \mathrm{tcpCO} \mathrm{CO}_{2}, \mathrm{tcpO}$ ) following a technique previously described (5). Pregnancy in the dog lasts $9 \mathrm{wk}$ and their gestational ages varied from 7 to $9 \mathrm{wk}$. All 12 dogs had similar anesthesia and surgical preparation, but the intermittent aortic occlusions were performed in only 10 dogs (Fig. 1). The last two dogs had a sham-operation during which the complete procedure on mother and fetus was performed, except there were no occlusions of the maternal abdominal aorta. Anesthesia was induced with 100 to $200 \mathrm{mg}$ of intravenous sodium pentobarbital and maintained with intravenous administration of ketamine hydrochloride (1 $\mathrm{mg} / \mathrm{kg}$ of body weight) and relaxation with an intravenous succinylcholine drip ( $500 \mathrm{mg}$ in $500 \mathrm{ml}$ normal saline solution). An endotracheal tube was placed and connected to a Harvard respirator. The abdominal aorta was exposed extraperitoneally following a technique previously described $(6,7)$, and a vascular occluder (Rhodes, Woodland Hills, CA) and an electromagnetic flow probe were placed around it. A uterine horn was exposed through a laparotomy incision and was incised over the lower back of one of the fetuses. A polyvinyl catheter was inserted into a fetal femoral artery and advanced into the descending aorta. The incised uterine edges were sutured in a circular manner to the back of the fetus, exposing a circle of fetal skin about $5 \mathrm{~cm}$ in diameter, onto which tcpO $\mathrm{O}_{2}$, tcpCO $\mathrm{CO}_{2}$, and tpH electrodes (Kontron, Everett, MA) were implanted. Careful manipulation reduced amniotic fluid loss to a minimum (less than $2 \mathrm{ml}$ ). The $\mathrm{tcpO}_{2}, \mathrm{tcpCO}$, and tpH electrodes, each previously calibrated with two media of known concentration, were implanted on the fetal skin according to previously described protocols $(6,7)$. Two 
ECG electrodes were fixed through the uterine wall onto the fetal shoulders, and connected to a cardiotachometer $(6,7)$.

The femoral artery catheter was connected through a threeway stopcock to a $0.9 \% \mathrm{NaCl}$ solution (containing $1 \mathrm{U}$ of heparin $/ \mathrm{ml}$ and delivering the solution at a speed of $1 \mathrm{ml} / \mathrm{h}$ ) and to a Statham pressure transducer. For fetal blood gas analysis, 0.08 to $0.1 \mathrm{ml}$ of fetal blood was drawn before, in the middle, and at the end of each experiment. This represented a negligible amount of blood loss inasmuch as it did not result in any changes in the studied parameters of the sham-operated fetuses. The blood gases and $\mathrm{pH}$ were determined on an automatic blood gas analyzer (Instrumentation Laboratory 1302, Lexington, MA) which was calibrated before use and gave accurate measurements with amount of blood as small as 0.08 to $0.1 \mathrm{ml}$. The experimental procedure was started after $\mathrm{tpH}, \mathrm{tcpO}$, and $\mathrm{tcpCO} \mathrm{CO}_{2}$ digital displays remained stable for at least $15 \mathrm{~min}$, and all parameters to be studied were within normal limits. The four sensors (FHR,

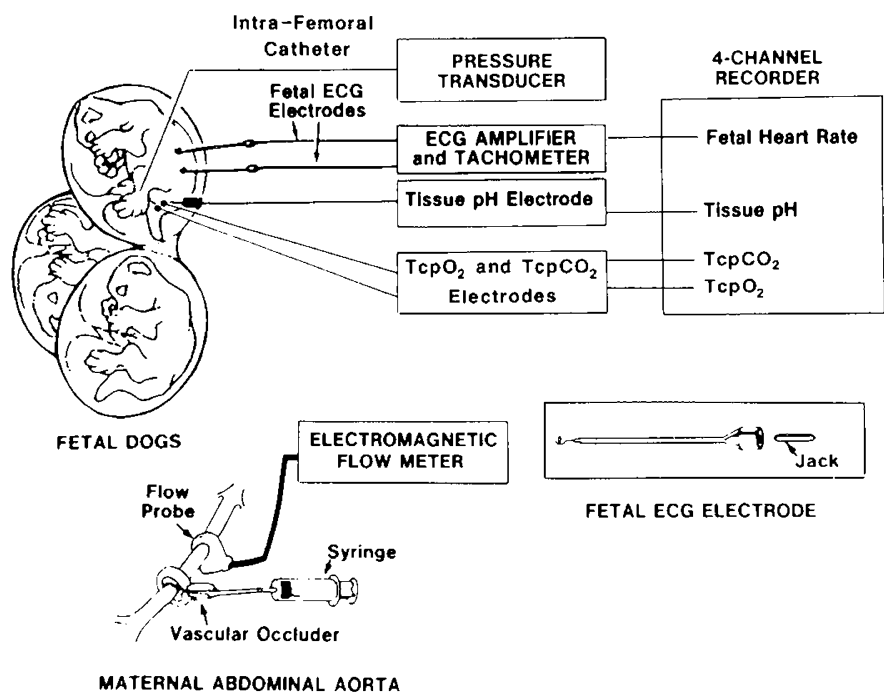

Fig. 1. After exposing the maternal abdominal aorta, a vasular occluder and flow probe are placed around it and connected to a flowmeter (bottom left). The fetal skin is exposed and the following sensors are placed on it (from left top to right bottom): 1) catheter from fetal femoral artery, connected to a pressure transducer; 2) two fetal EKG electrodes (magnified on bottom right); 3) tissue $\mathrm{pH}$ electrode; 4) $\mathrm{tcpO}_{2}$ electrode; 5) $\mathrm{tcpCO}_{2}$ electrode. All these electrodes are connected to the fourchannel recorder on right.
tcpCO $\mathrm{CO}_{2}, \mathrm{tcO}_{2}$, and $\left.\mathrm{tpH}\right)$ were connected to a four channel recorder (Sensor Medics, Anaheim, CA).

The maternal aorta was rapidly and totally occluded for successive episodes of $1 \mathrm{~min}$ each, these episodes being separated by various periods of rest: $4,3,2$, and 1 min in each group of two dogs. For the last two dogs the occlusions were extended over a 2 -minute period separated by a period of 1 -min rest. These occlusions were repeated until the tissue $\mathrm{pH}$ reached a value close to 7.05. At this point the fetus was allowed to recover for 1 $h$ during which all variables returned to normal. In three cases, oxygen was added to the inspiratory gas of the dog to facilitate recovery. This entire cycle was repeated twice.

After completion of the experimental protocol (once all values had returned to normal) the fetus with the implanted electrodes was delivered and an Apgar score was determined at $5 \mathrm{~min}$ of life. This score was adapted from the original criteria as defined by Virginia Apgar (8), except that the color was evaluated on the neonatal tongue rather than the skin. At the end of each study, the animals were put to sleep with intravenous pentobarbital. All electrodes were removed for recalibration and to determine any drift.

\section{RESULTS}

The data are summarized in Table 1. FHR had a mean value of $154( \pm 4$ SEM) beats/min before the aortic occlusions. It droppped to 104 ( \pm 9 SEM) during the deceleration when tpH was near 7.05 and it was $158( \pm 3$ SEM $)$ after recovery. With the aortic occlusions, $\mathrm{pO}_{2}$ and $\mathrm{pH}$ went down, whereas $\mathrm{pCO}_{2}$ went up. The specific relationships between these data will now be described.

Differences between tissue and blood variables (Table 1). Initially the arterial blood $\mathrm{pO}_{2}$ and $\mathrm{pH}$ were slightly higher, and the arterial blood $\mathrm{pCO}_{2}$ slightly lower than the corresponding $t$ and tc values. The mean blood and t-tc values-were, respectively, 35 $\left( \pm 2\right.$ SEM) and $33\left( \pm 2\right.$ SEM) $\mathrm{mm} \mathrm{Hg}$ for $\mathrm{pO}_{2}, 41$ ( \pm 3 SEM) and $44( \pm 2 \mathrm{SEM}) \mathrm{mm} \mathrm{Hg}$ for $\mathrm{pCO}_{2}$, and $7.33( \pm 0.02 \mathrm{SEM})$ and 7.30 $( \pm 0.03 \mathrm{SEM})$ for $\mathrm{pH}$. With increased hypoxic stress, the differences increased markedly and reached their greatest values at the maximum of hypoxia: at this stage, the respective blood and $t-t c$ values were $19( \pm 3$ SEM $)$ and $10( \pm 1$ SEM $) \mathrm{mm} \mathrm{Hg}$ for $\mathrm{pO}_{2}, 72$ $( \pm 5 \mathrm{SEM})$ and $112( \pm 7 \mathrm{SEM}) \mathrm{mm} \mathrm{Hg}$ for $\mathrm{pCO}_{2}$, and $7.18( \pm$ 0.05 SEM) and $7.05( \pm 0.07$ SEM) for $\mathrm{pH}$. After recovery, all values returned more or less to the original values: $37 \pm 2$ and $34 \pm 2$ SEM for $\mathrm{pO}_{2}, 37 \pm 3$ and $40 \pm 3$ SEM for $\mathrm{pCO}_{2}$, and $7.32 \pm 0.02$ and $7.30 \pm 0.06 \mathrm{SEM}$ for $\mathrm{pH}$.

Patterns of response to repeated aortic occlusions. Five different

Table 1. Summary of fetal data

\begin{tabular}{|c|c|c|c|c|c|c|c|c|c|c|c|c|c|c|c|c|c|c|c|c|c|}
\hline \multicolumn{8}{|c|}{ Before experiment } & \multicolumn{7}{|c|}{ Condition when tpH was 7.05} & \multicolumn{7}{|c|}{ End of recovery } \\
\hline Dog & FHR & $\begin{array}{c}\text { Blood } \\
\mathrm{pH}\end{array}$ & $\mathrm{tpH}$ & $\begin{array}{c}\text { Blood } \\
\mathrm{pO}_{2}\end{array}$ & $\begin{array}{c}\mathrm{tc} \\
\mathrm{pO}_{2}\end{array}$ & $\begin{array}{l}\text { Blood } \\
\mathrm{pCO}_{2}\end{array}$ & $\begin{array}{c}\mathrm{tc} \\
\mathrm{pCO}_{2}\end{array}$ & FHR & $\begin{array}{c}\text { Blood } \\
\mathrm{pH}\end{array}$ & $\mathrm{tpH}$ & $\begin{array}{c}\text { Blood } \\
\mathrm{pO}_{2}\end{array}$ & $\begin{array}{c}\mathrm{tc} \\
\mathrm{pO}_{2}\end{array}$ & $\begin{array}{l}\text { Blood } \\
\mathrm{pCO}_{2}\end{array}$ & $\begin{array}{c}\mathrm{tc} \\
\mathrm{pCO}_{2}\end{array}$ & FHR & $\begin{array}{c}\text { Blood } \\
\mathrm{pH}\end{array}$ & $\mathrm{tpH}$ & $\begin{array}{c}\text { Blood } \\
\mathrm{pO}_{2}\end{array}$ & $\begin{array}{c}\text { tc } \\
\mathrm{pO}_{2}\end{array}$ & $\begin{array}{c}\text { Blood } \\
\mathrm{pO}_{2}\end{array}$ & $\begin{array}{c}\mathrm{tc} \\
\mathrm{pCO}_{2}\end{array}$ \\
\hline 1 & 155 & 7.34 & 7.34 & 38 & 35 & 38 & 39 & 40 & 7.18 & 7.06 & 21 & 10 & 68 & 108 & 148 & 7.28 & 7.32 & 43 & 36 & 40 & 40 \\
\hline 2 & 162 & 7.36 & 7.34 & 23 & 21 & 42 & 48 & 100 & 7.17 & 7.06 & 12 & 6 & 54 & 78 & 155 & 7.33 & 7.29 & 25 & 24 & 39 & 45 \\
\hline 3 & 159 & 7.28 & 7.24 & 27 & 25 & 46 & 49 & 112 & 7.16 & 7.04 & 17 & 9 & 82 & 135 & 164 & 7.31 & 7.28 & 34 & 34 & 46 & 48 \\
\hline 4 & 148 & 7.38 & 7.37 & 41 & 41 & 32 & 34 & 91 & 7.19 & 7.08 & 22 & 14 & 77 & 113 & 157 & 7.37 & 7.34 & 42 & 40 & 35 & 37 \\
\hline 5 & 163 & 7.31 & 7.28 & 38 & 36 & 44 & 50 & 140 & 7.17 & 7.03 & 22 & 12 & 98 & 159 & 165 & 7.31 & 7.30 & 47 & 40 & 22 & 25 \\
\hline 6 & 149 & 7.38 & 7.32 & 41 & 40 & 38 & 40 & 105 & 7.16 & 7.04 & 18 & 9 & 61 & 91 & 149 & 7.32 & 7.29 & 34 & 31 & 37 & 42 \\
\hline 7 & 142 & 7.32 & 7.30 & 42 & 38 & 45 & 45 & 98 & 7.15 & 7.03 & 16 & 7 & 95 & 132 & 158 & 7.35 & 7.30 & 46 & 39 & 26 & 31 \\
\hline 8 & 155 & 7.36 & 7.34 & 35 & 31 & 45 & 47 & 100 & 7.20 & 7.11 & 18 & 10 & 61 & 105 & 152 & 7.28 & 7.28 & 34 & 30 & 39 & 40 \\
\hline 9 & 151 & 7.39 & 7.24 & 30 & 26 & 34 & 35 & 130 & 7.20 & 7.06 & 20 & 12 & 54 & 90 & 153 & 7.29 & 7.28 & 36 & 35 & 37 & 39 \\
\hline 10 & 158 & 7.29 & 7.24 & 33 & 32 & 45 & 50 & 127 & 7.17 & 7.05 & 19 & 11 & 70 & 105 & 160 & 7.36 & 7.30 & 32 & 29 & 50 & 55 \\
\hline Mean & 154 & 7.33 & 7.30 & 35 & 33 & 41 & 44 & 104 & 7.18 & 7.05 & 19 & 10 & 72 & 112 & 158 & 7.32 & 7.30 & 37 & 34 & 37 & 40 \\
\hline \pm SEM & \pm 4 & \pm 0.02 & \pm 0.03 & \pm 2 & \pm 2 & \pm 3 & \pm 2 & \pm 9 & \pm 0.05 & \pm 0.07 & \pm 3 & \pm 1 & \pm 5 & \pm 7 & \pm 3 & \pm 0.02 & \pm 0.06 & \pm 2 & \pm 2 & \pm 3 & \pm 3 \\
\hline
\end{tabular}

* Dog 1 is shown in Figure 2; dog 5 is shown in Figure 3; and dog 8 is shown in Figure 4. FHR in beats/min; values in middle column are the deepest drop during late deceleration. $\mathrm{pO}_{2}$ and $\mathrm{pCO}_{2}$ in $\mathrm{mm} \mathrm{Hg} . t$ test: $p<0.001$ when comparing data before experiment to data at tpH 7.05 , or when compari8ng data at $\mathrm{tpH} 7.05$ to data after recovery. When comparing data before experiment to data after recovery, $p$ NS. 
Table 2. Relationship between patterns of cyclic anoxia and different components of fetal distress*

\begin{tabular}{|c|c|c|c|c|c|c|c|c|c|}
\hline \multirow[b]{2}{*}{ Dog } & \multicolumn{2}{|c|}{ Cycling pattern } & \multirow[b]{2}{*}{$\begin{array}{l}\text { Time to reach } \\
\text { tpH } 7.05\end{array}$} & \multicolumn{6}{|c|}{ Successive time periods for appearance of variation in: recovery } \\
\hline & Occlusion & Rest & & $\mathrm{TcpO}_{2}$ & $\begin{array}{c}\text { Late } \\
\text { deceleration }\end{array}$ & $\mathrm{TcpCO}_{2}$ & $\mathrm{tpH}$ & tpH:7.05 & $\begin{array}{l}\text { Recovery } \\
\text { time }\end{array}$ \\
\hline 1 & 1 & 4 & 174 & 66 & 18 & 12 & 18 & 60 & $42^{*}$ \\
\hline 2 & 1 & 4 & 216 & 54 & 30 & 28 & 16 & 88 & 54 \\
\hline 3 & 1 & 3 & 202 & 50 & 36 & 28 & 36 & 52 & 82 \\
\hline 4 & 1 & 3 & 180 & 42 & 32 & 32 & 16 & 58 & 56 \\
\hline 5 & 1 & 2 & 118 & 30 & 28 & 14 & 18 & 28 & $30^{*}$ \\
\hline 6 & 1 & 2 & 86 & 22 & 18 & 6 & 10 & 30 & 54 \\
\hline 7 & 1 & 1 & 66 & 12 & 10 & 12 & 16 & 16 & $28^{*}$ \\
\hline 8 & 1 & 1 & 42 & 12 & 4 & 4 & 2 & 20 & 32 \\
\hline 9 & 2 & 1 & 36 & 2 & 0 & 6 & 10 & 18 & 70 \\
\hline 10 & 2 & 1 & 50 & 4 & 2 & 4 & 12 & 28 & 48 \\
\hline
\end{tabular}

* All times are given in min. For dog 1 for instance, with a cycling pattern of one minute occlusion with 4 min rest, it took 174 min to reach tpH 7.05, divided as follows: $66 \mathrm{~min}$ for $\mathrm{tcpO}_{2}$ to start showing a noticeable drop; then another $18 \mathrm{~min}$ for the late deceleration to first appear; then another $12 \mathrm{~min}$ for $\mathrm{tcpCO} \mathrm{CO}_{2}$ to start going up; then another $18 \mathrm{~min}$ for tpH to start going down; and finally another $60 \mathrm{~min}$ for tpH to reach 7.05 .

$\dagger$ Recovery time: From tpH $=7.05$ to return to original value, without or with $\left(^{*}\right)$ oxygenation.
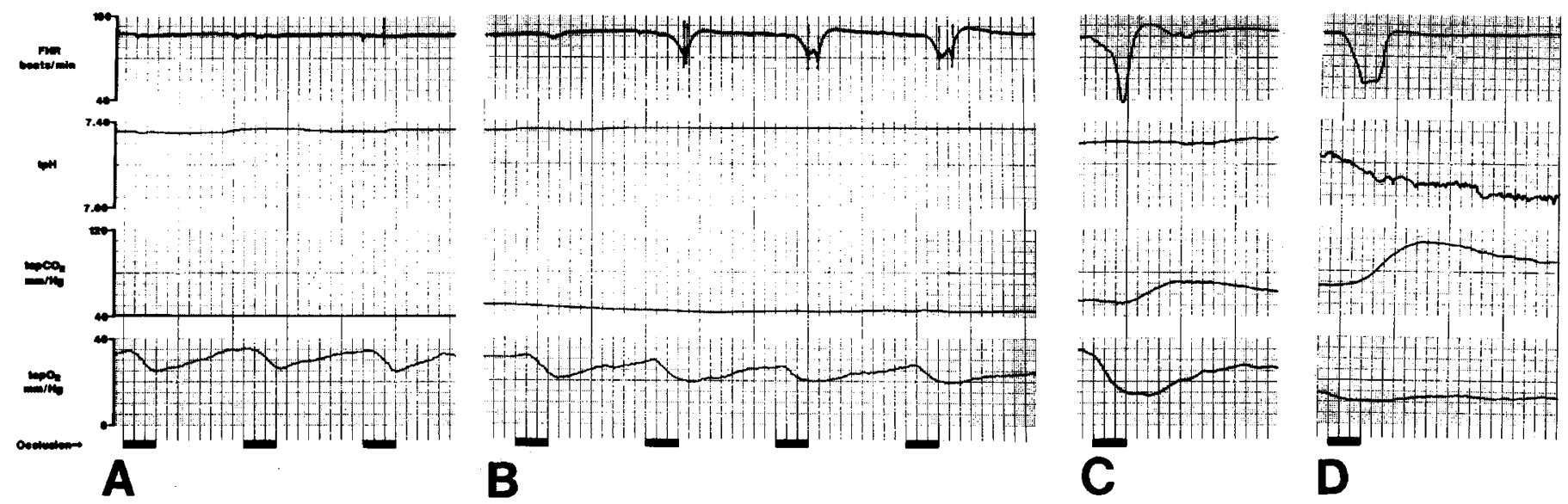

Fig. 2. One-min aortic occlusion with 4 min rest. From left to right: $A, \mathrm{TcpO}_{2}$ shows cyclic variations with return to normal before the next occlusion (first three occlusions on the left). $B$, the cyclic variations of $t \mathrm{cpO}_{2}$ are at a lower level. Note appearance of late deceleration first progressively increasing in severity, then taking on stable pattern (next four occlusions, in the middle). $C$, in addition to late deceleration, tcpCO ${ }_{2}$ demonstrates a temporary rise after each occlusion. $\mathrm{TcpCO}_{2}$ does not completely return to normal after the occlusion (second occlusion from the right). $D, \Upsilon_{\mathrm{cpO}}$ is now stabilized a low level. There is a progressive drop in tpH almost symmetric and opposite to tcpCO $\mathrm{Cariations}_{2}$ (last occlusion on right).

periods were identified in succession (Table 2). 1) A latency period during which none of the four recorded variables (FHR, tpH, tcpO $\mathrm{O}_{2}, \mathrm{tcpCO} \mathrm{C}_{2}$ ) showed noticeable changes. 2) $\mathrm{TcpO}_{2}$ was the first to change. With each aortic occlusion $\mathrm{TcpO}_{2}$ declined rapidly, and this was followed by a slow recovery when the aortic occlusion was lifted. TcpO $\mathrm{T}_{2}$ did not completely recover by the time the next occlusion occurred, and it eventually reached a lower plateau with a cyclic pattern (Figs. $2 A$ and $B, 3,4$ ). 3) A FHR late deceleration appeared once $\mathrm{tcpO}_{2}$ reached a lower level. A lag period of several seconds between the beginning of the aortic occlusion and the beginning of the FHR deceleration was evident. The depth of the deceleration varied from one animal to another and from one occlusion to another (Figs. $2 B$ and 4). 4) $\mathrm{TcpCO}_{2}$ began to increase after tcpO had reached a lower level. $\mathrm{TcpCO}_{2}$ variations could also be cyclic. Similar to tcpO $\mathrm{O}_{2}$, recovery was not complete (Fig. $2 C$ and $D$ ); but differently from $\mathrm{tcpO}_{2}$, there was no plateau achieved, and $\mathrm{tcpCO} \mathrm{C}_{2}$ kept increasing as long as the aorta was repeatedly occluded (Figs. 3 and 4). 5) $\mathrm{TpH}$ was the last variable to show deterioration, decreasing until the aortic occlusions were discontinued when tpH reached 7.05. The drop in $\mathrm{tpH}$ was straight or irregular (Figs. 3 and 4).

Severity of responses. Whereas the five successive patterns were seen in all fetuses, each episode was shorter when aortic occlu-

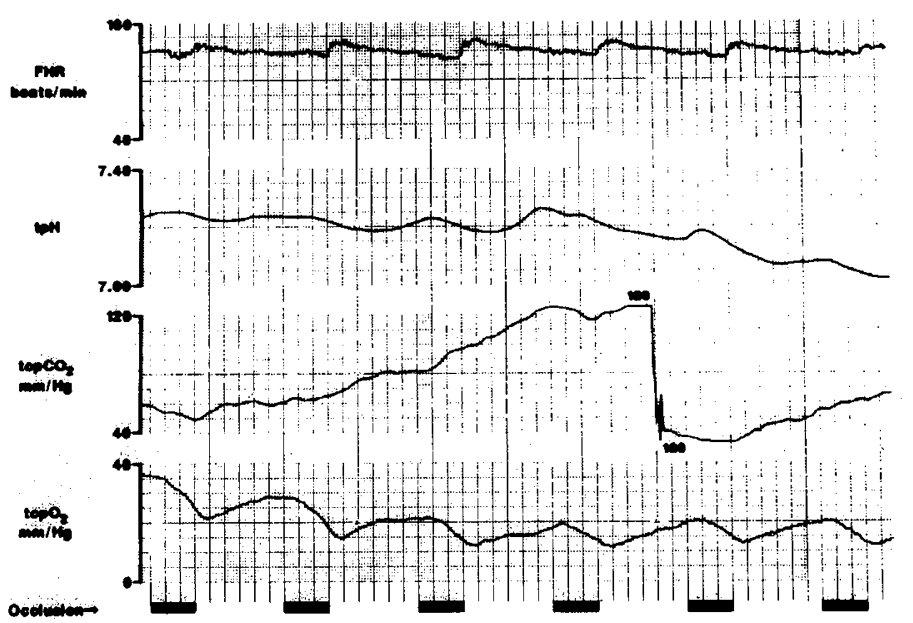

Fig. 3. One-min occlusion, with $2 \mathrm{~min}$ rest. $\mathrm{TcpO}_{2}$ decreases cyclically to a lower level with each occlusion. FHR shows a mild late deceleration followed by a reactive tachycardia with each occlusion. After a delay in relation to $t c p \mathrm{O}_{2}$ drop, tcpCO $\mathrm{C}_{2}$ goes up continuously. After a delay in relation to $t \mathrm{cpCO}_{2}$ rise, tpH begins to fall continuously. $T \mathrm{TpCO}_{2}$ was rescaled after fourth occlusion because it went off scale. 


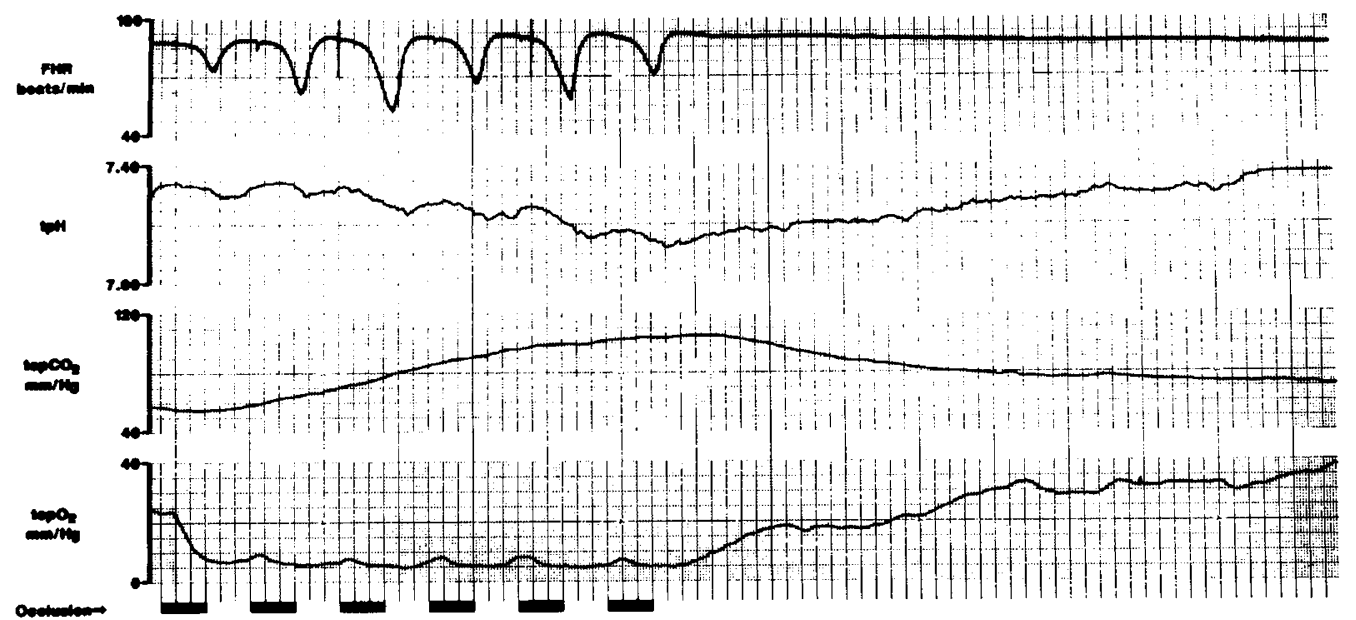

Fig. 4. One-min occlusion with 1 min rest. $\mathrm{TcpO}_{2}$ stabilizes at a lower level with minimal variations and FHR late decelerations increase in severity. The delayed rise in $\mathrm{tcpCO}_{2}$ and further delayed drop in tpH are almost symmetrically opposite. The recovery follows a reverse pattern.

Table 3. Range of maternal parameters during protocol*

\begin{tabular}{cccccc}
\hline Dog & $\begin{array}{c}\mathrm{BP} \\
(\mathrm{mm} \mathrm{Hg})\end{array}$ & $\begin{array}{c}\text { Pulse } \\
(\mathrm{min})\end{array}$ & $\begin{array}{c}\text { Blood pH } \\
(\mathrm{mm} \mathrm{Hg})\end{array}$ & $\begin{array}{c}\mathrm{Blood} \mathrm{pO}_{2} \\
(\mathrm{~mm} \mathrm{Hg})\end{array}$ & $\begin{array}{c}\mathrm{Blood} \mathrm{pCO}_{2} \\
(\mathrm{~mm} \mathrm{Hg})\end{array}$ \\
\hline $1 \dagger$ & $100 / 70-113 / 75$ & $68-79$ & $7.30-7.42$ & $42-60$ & $34-39$ \\
2 & $102 / 71-105 / 74$ & $68-72$ & $7.34-7.37$ & $40-43$ & $38-42$ \\
3 & $108 / 65-111 / 72$ & $64-67$ & $7.30-7.32$ & $35-38$ & $40-40$ \\
4 & $95 / 61-104 / 70$ & $80-85$ & $7.38-7.42$ & $39-41$ & $36-39$ \\
$5 \dagger$ & $100 / 72-110 / 75$ & $65-76$ & $7.29-7.39$ & $45-54$ & $35-45$ \\
6 & $93 / 60-97 / 65$ & $72-77$ & $7.40-7.44$ & $38-41$ & $37-40$ \\
$7 \dagger$ & $95 / 64-104 / 70$ & $64-82$ & $7.35-7.44$ & $42-57$ & $34-42$ \\
8 & $104 / 70-105 / 72$ & $75-76$ & $7.32-7.33$ & $42-44$ & $38-39$ \\
9 & $105 / 70-108 / 70$ & $67-70$ & $7.30-7.33$ & $34-38$ & $43-44$ \\
10 & $93 / 60-98 / 66$ & $71-74$ & $7.28-7.32$ & $40-41$ & $42-46$ \\
Mean & $100 / 66-106 / 71$ & $69-76$ & $7.32-7.38$ & $40-46$ & $38-42$ \\
\hline
\end{tabular}

$* t$ test: $p$ NS.

$\dagger \mathrm{O}_{2}$, maternal oxygenation during recovery.

sions were divided by shorter intervening rest periods $(4,3,2$, and $1 \mathrm{~min}$ ) (Table 2). It took 216 and $174 \mathrm{~min}$ to reach a tpH of 7.05 for the two dogs stressed by a 1 -min occlusion with 4min rest. In contrast only 42 and 66 min were necessary in the two dogs where the pattern was a 1-min occlusion and 1-min rest.

Recovery and delivery. The recovery period after the last aortic occlusion was characterized by a reversal of previously noted patterns; this was similar in all cases (Fig. 4). The FHR returned to normal immediately after the last last deceleration. Five to 10 min later, $t c \mathrm{pO}_{2}$ started to rise slowly and then more rapidly. When it neared its original value, $\mathrm{tcpCO}_{2}$ started to fall. Two to $3 \mathrm{~min}$ later, tpH started its upward return to normal. The recovery curve of $t c p \mathrm{O}_{2}, \mathrm{tcpCO}$, and tpH seemed to be both steady and regular. Maternal administration of oxygen, when added to the inspiratory gas through the Harvard respirator, consistently enhanced the recovery.

After the aortic occlusions were discontinued and all the values had returned to normal, the fetus under study was delivered and all the electrodes were removed. All such fetuses started to breathe spontaneously and were given an Apgar score at $5 \mathrm{~min}$ of life which varied between 7 and 10. Recalibration of the continuous electrodes after removal showed minimal drift (less than $10 \%$ ) as in our the previous report (5).

Sham operation. In the two control dogs with sham operation, only minimal variation in FHR, $\mathrm{pO}_{2}, \mathrm{pCO}_{2}$, and $\mathrm{pH}$ (arterial blood as well as tc) were noted over $4 \mathrm{~h}$ of continuous observation, indicating no fetal deterioration during these studies.

Maternal status during the experiments. All parameters of maternal condition including blood pressure, heart rate, $\mathrm{pH}$, $\mathrm{pO}_{2}$, and $\mathrm{pCO}_{2}$, were found to remain stable and within normal limits throughout each experiment. These are summarized in Table 3.

\section{DISCUSSION}

From the observations previously reported (5) and from those reported herein it may be concluded that alterations in $\mathrm{pO}_{2}$, $\mathrm{pCO}_{2}$, and $\mathrm{pH}$ appear first and are more accentuated with the tc sensors, and appear later in blood drawn from the abdominal aorta. The other conclusion is that, with repeated aortic occlusions in the pregnant dog, the fetus will display a progressive state of compromise characterized by the following sequence. 1) An initial fall in $\mathrm{tcpO}$, then in arterial $\mathrm{pO}_{2} ; 2$ ) FHR decelerations; 3) $\mathrm{TcpCO}_{2}$, then arterial $\mathrm{pCO}_{2}$ rise; 4) $\mathrm{TpH}$, then arterial $\mathrm{pH}$ fall.

The presence of hypoxia before hypercarbia and the appearance of both first in tc tissues then in arterial blood can be explained the following way: $\mathrm{O}_{2}$ variations are not buffered, whereas $\mathrm{CO}_{2}$ variations are, and buffer mechanisms are more sophisticated in blood than in tissues. Physiological variations in oxygenation are therefore wider and become manifest more rapidly. When the lower limit of these physiological variations has been reached, FHR may have already responded with a deceleration which, in this early stage, is of limited clinical significance. On the contrary, $\mathrm{CO}_{2}$ and $\mathrm{pH}$ variations appear much later after they have exceeded buffer mechanisms. Consequently they indicate a greater severity of distress.

How much of these observations can be applied to human 
conditions? It is very difficult to compare the effect of occlusion of the abdominal aorta in the pregnant dog to the effect of the contracting uterus in pregnant women because the experimental conditions and the clinical situation are too dissimilar. However, it is well known that FHR late deceleration is a relatively rapid and early response to hypoxia and is not associated initially with acidosis (9). The drop in arterial $\mathrm{pH}$ beyond that seen during normal labor is an advanced sign of fetal distress, as it is the final component of the previously described sequence. The clinical observation that some late decelerations are not associated with a $\mathrm{pH}$ drop, whereas others are, now becomes clear: the former precede the latter. It is difficult to differentiate fetal "stress" from "distress" solely on the appearance of the late deceleration (10, 11).

Another logical conclusion that can be applied to the human condition is that fetal hypoxia initially affects nonvital organs such as skin and subcutaneous tissue, then vital organs such as the heart: this may explain the late aspect of the FHR deceleration, but other mechanisms are likely (12).

Several researchers have studied fetal distress in pregnant animals, using different modalities to interrupt uterine blood flow. Wilkening and Meschia (10) and other authors have generally used chronic preparations. The acute surgical preparation presented herein was done under general anesthesia, raising the question of how much the insults of surgery and anesthesia may have affected the physiological responses of the fetal dog.

There is a vacuum of information about that interval between the earliest (late FHR deceleration) and the more advanced (fall in blood $\mathrm{pH}$ ) sign of fetal compromise. The application of continuous monitoring of $\mathrm{pH}, \mathrm{pO}_{2}$, and $\mathrm{pCO}_{2}$ on the fetal scalp may be useful in filling this void. Tc electrodes are commonly used in neonatal intensive care units but their use in obstetrics has been associated with technical difficulties yet to be solved.

Hopefully, a more complete surveillance of fetal metabolism during labor will become possible, a result of which may be a reduction in the rate of cesarean section for fetal "distress," too often solely based on the earliest appearance of a FHR deceleration. However, this type of monitoring may allow appropriate intervention before serious acidemia develops. In this way a fetus born in the best possible condition will result while maternal operative intervention is kept to the necessary minimum. The ultimate goal of a healthy mother and baby will be one step closer.

\section{REFERENCES}

1. Young BK, Katz M, Klein SA 1979 The relationship of heart rate patterns and tissue $\mathrm{pH}$ in the human fetus. Am J Obstet Gynecol 134:685-690

2. Antoine C, Silverman F, Young BK 1982 Current status of continuous fetal pH monitoring. Clin Perinatol 9:409-422

3. Zuspan FP, Quilligan EJ, Iams JD 1979 Predictors of intrapartum fetal distress: the role of electronic fetal monitoring. Am J Obstet Gynecol 135:287-291

4. La Gamma EF, Krauss AN, Auld PAM 1982 Tissue surface pH monitoring during reduced blood flow. J Perinatol Med 10:174-180

5. Abitbol MM, Monheit AG, Stone ML 1986 Arterial pO2, pCO2, and pH versus tcpO2, tcpCO2 and tpH in the fetal dog. Am J Obstet Gynecol 155:437-443

6. Abitbol MM 1982 Fetal heart rate and tissue $\mathrm{pH}$ changes associated with repetitive aortic occlusion in the pregnant dog. Am J Obstet Gynecol $143: 430-439$

7. Abitbol MM 1981 A simplified technique to produce toxemia in the pregnant dog. Am J Obstet Gynecol 139:526-534

8. Apgar V 1953 A proposal for a new method of evaluation of the newborn infant. Anesth Analg 32:260

9. Parer JT, Krueger TR, Harris JL 1980 Fetal oxygen consumption and mechanisms of heart rate response during artificially produced late decelerations of fetal heart rate in sheep.Am J Obstet Gynecol 136:478-482

10. Wilkening RB, Meschia G 1983 Fetal oxygen uptake, oxygenation, and acidbase balance as a function of uterine blood flow. Am J Physiol 244:H749H755

11. Bocking AD, Harding R, Wickham PJ 1986 Effects of reduced uterine blood flow on accelerations and decelerations in heart rate of fetal sheep. Am $\mathbf{J}$ Obstet Gynecol 154:329-335

12. Myers RE, Mueller-Heubach E, Adamsons K 1973 Predictability of the state of fetal oxygenation from a quantitative analysis of the components of late deceleration. Am J Obstet Gynecol 115:1083 